\title{
Kaynaştırma Uygulamasını Yürüten Öğretmenlerin Duygusal Emek ve Tükenmişlik Düzeylerinin İncelenmesi
}

\section{Examination of the Emotional Labor and Burnout Levels of the Teachers Conducting the Mainstreaming Application}

Öğr. Gör. Gül Kadan¹, Çankırı Karatekin Üniversitesi Sağlık Bilimleri Fakültesi Çocuk Gelişimi Bölümü, gulkadan@gmail.com

Prof. Dr. Neriman Aral, Ankara Üniversitesi Sağlık Bilimleri Fakültesi Çocuk Gelişimi Bölümü, aralneriman@gmail.com

\section{$\ddot{O} z$}

Eğitim bir toplumun geleceğinde oldukça önemli bir yere sahiptir. Ancak bir toplumun geleceğinde, sadece eğitim tek başına bir anlam ifade etmez. Aynı zamanda bu eğitim faaliyetlerini yerine getirecek öğretmenlerin de, tutumu ve bilgisi bu süreçte önemlidir. Üstelik öğretmen sınıfında atipik gelişim gösteren öğrencileri de içine alacak şekilde eğitim-öğretim faaliyetlerini geliştirebilmelidir. Ancak öğretmenlerin atipik gelişim gösteren öğrencileriyle çalışırken, aynı zamanda duygusal anlamda bir emek harcamaları gerekebilir. Duygusal emek, öğretmenlerin eğitim faaliyetlerini yürütürken kullandıkları duygu ve davranışları düzenleyebilme kapasitesi olarak tanımlanmakla birlikte tükenmişliğe yol açabileceği de ifade edilmektedir. Özellikle kaynaştırma uygulamasını yürüten öğretmenlerin duygusal emek davranışlarını yoğun olarak kullanmaları sonucunda tükenmişliği de sıklıkla yaşayabilecekleri düşünülebilir. Bu düşünceden hareketle araştırmada, kaynaştırma uygulamasını yürüten öğretmenlerin duygusal emek ve tükenmişlik düzeylerinin bazı değişkenlere göre farklılaşıp farklılaşmadığını belirlemek ve duygusal emek ile tükenmişlik düzeyleri arasında ilişki olup olmadığını saptamak amaçlanmıştır.

Tanımlayıcı olarak gerçekleştirilen araştırma, Çankırı İl Milli Eğitim Müdürlüğ̈’ne bağlı olan ilk ve ortaöğretim düzeyinde, sınıfinda kaynaştırma öğrencisi olan 70 öğretmenle gerçekleştirilmiştir. Araştırma için etik kurul onayı Çankıı İl Milli Eğitim Müdürlüğü’nden alınmış, alınan etik kurul onayından sonra okullara gidilerek çalışmanın amacı okul yönetici ve öğretmenlerine anlatılmış, araştırmaya katılmayı gönüllü olarak kabul eden öğretmenlerle çalısıılmıştır. Araştırmada veri toplama aracı olarak "Genel Bilgi Formu”, "Duygusal Emek Ölçeği’ ve "Tükenmişlik Ölçeği” kullanılmıştır. Araştırmaya dahil edilen öğretmenlerin \%50’si kadın, \%50’si erkek, \%42,9’u 21-30 yaş grubunda, \%31,4’ü 16 yll ve üzeri kıdeme sahipken, \%64,3 öğretmenin sınıfinda zihinsel yetersizliğe sahip öğrenci bulunmaktadır.

Araşıırma sonucunda cinsiyetin, yaşın, mesleki kıdemin, kaynaştırma öğrencisinin yetersizlik türünün duygusal emek ölçeğinin bazı alt boyutlarında, medeni durumun, kaynaştırma öğrencisinin yetersizlik türünün ise tükenmişlik ölçeğinin duyarsızlaşma alt boyutunda anlamlı farklilğga neden olduğu görülürken, duygusal emek ve tükenmişlik ölçeğinin alt boyutları arasında anlamlı bir ilişki bulunmuştur. Araştırmadan elde edilen sonuçlara bağı olarak,

\footnotetext{
1 Sorumlu Yazar
} 
kaynaştırma uygulamasını yürüten öğretmenlerin daha çok desteklenmesi, öğretmenlere özel eğitim konusunda hizmet içi eğitimlerin verilmesi ve var olan uygulamaların etkililiğinin arttırılması önerilebilir.

Anahtar Kelimeler: Atipik gelişim gösteren çocuklar, öğretmen, eğitim-öğretim, eğitim hakkı, kaynaştırma

\begin{abstract}
Education has a very important place in the future of a society. However, education does not make a sense alone in the future of a society. Also the attitudes and knowledge of teachers who will carry out these educational activities are also important in this process. Moreover teacher should be able to develop educational activities including the students showing atypical development, teaches may also need to spend an emotional labor. Even though emotional labor is defined as the teachers' capacity of regulating their emotions and behaviors used while conducting the educational activities, it also stated that it may lead to burnout. Particularly, it can be considered that especially teachers who carry out the mainstreaming application frequently experience burnout as a result of intensive use of emotional labor behaviors. It is aimed to determine whether the emotional labor and burnout levels of the teachers who carry out the mainstreaming in the research are differentiated according to some variables and to determine whether there is a relationship between emotional labor and burnout. This descriptive study was conducted with to teachers who had mainstreaming students in their class at primary and secondary school level affiliated with Provincial Directorate for National Education of Çankırı. Ethics committee approval for the study was taken from Provincial Directorate for National Education of Çankırı, after the approval of the ethics committee, the school administrators and teachers were informed about the purpose of the study by going to the school and the study was conducted with the teachers who were voluntary to participate in the study. "General Information Form", "Emotional Labor Scale” and "Burnout Inventory” were used as data collection tool in the study. $50 \%$ of the teachers included in the study were female $50 \%$ were male; $42,9 \%$ were in age group of $21-30$ years, $31,4 \%$ had a seniority of 16 years and more and $64,3 \%$ had a students with mental deficiency in their class. As a result of the study, it is seen that gender, age, occupational seniority, deficiency type of the mainstreaming students cause a significant difference in some subscales of emotional labor scale, and marital status and deficiency type of the mainstreaming students cause a significant difference in depersonalization subscale of burnout inventory, whereas, a significant correlation was found between the subscales of emotional labor scale and the subscales of burnout inventory. Based on the results obtained from the study, it can be recommended to support the teachers who conduct the mainstreaming application more, provide in service trainings on special education to the teachers and increase the effectiveness of the existing practices, ensure school-family- teacher cooperation.
\end{abstract}

Keywords: Children with atypical development, teacher, education-training, education right, mainstreaming students.

\title{
Giriş
}

Eğitim, bir toplumun gelişmesinde ve kalkınmasında en önemli öğelerden biridir. Eğitim kurumlarında bu amaçların yerine getirilebilmesinde ise öğretmenlere çok büyük rol ve sorumluluklar düşmektedir. Özellikle çocuğun kişiliğinin şekillenmeye başladığ1 dönemlerde, öğretmenlerin gerek uygun-rol model 
olmaları, gerekse başarılı eğitim programları uygulayabilmelerinin hayati önem taşıdığı bilinmektedir (Brookfield, 2017; Fullan ve Hargreaves, 2014; Karataş, 2013). Öğretmenlerin bu sorumlulukları sınıflarında tipik gelişim gösteren çocukları içine aldığı gibi, aynı zamanda atipik gelişim gösteren çocukları da kapsayabilmelidir (Diken, 2015). Tipik gelişim gösteren çocukların nasıl ki, eğitim hakkına, korunmaya ve sosyal bir birey olmaya hakları varsa, bu çocuklarında aynı haklara sahip oldukları göz ardı edilmemelidir (Coşkun, Gür ve Aykutlu, 2014; Seyhan ve Gültekin- Akduman, 2015).

Özel gereksinimli olan çocukların potansiyellerini geliştirip, topluma kazandırılabilmeleri açısından eğitimin önemi yadsınamayacağ1 gibi, bu eğitimi gerçekleştirecek olan öğretmenlerin öneminin de yadsınamayacağı ortadadır. Öğretmenlerin özel gereksinimli olan çocuklarla çalışırken, çocukların bireysel farkl1lıklarını göz önüne alarak, özel stratejiler uygulayabilmeleri oldukça önemlidir (Karasu, Girgin ve Gürgür, 2015). Öğretmenlerin eğitim faaliyetleri sırasında, özel stratejileri uygulayabilmelerinin yanında önyargısız bir yapıda olmaları, çok sabırlı ve sakin olabilmeleri, empati yapabilmeleri gerekmektedir (Coe, Alaisi, Higgins ve Major, 2014). Tüm bu özellikler de kaynaştırma uygulamasını yürüten öğretmenlerin çocuklara yönelik daha fazla duygusal emek harcamalarına neden olabilir.

Duygusal emek, kişilerin yüz yüze iletişimleri sırasında ortaya çıkan, karşıdaki kişinin duygularını anlama, empati yapabilmeyi gerektiren, karşıllklı iletişim ve etkileşimi içeren organizasyonda görevli olan kişiler tarafindan işlerin yürütülebilmesi için harcanan emek ve bu emeği planlayabilme ve uygulayabilme yeteneği olarak tanımlanmaktadır (Guy, Newman ve Mastracci, 2015; Gün- Eroğlu, 2014). Kişilerin mesleklerini yerine getirirken, rol yapmak zorunda kalmaları ise birtakım sorunlara neden olabilir ki, bunlardan belki de en önemlisi tükenmişliktir (Şat, Amil ve Özdevecioğlu, 2016). Nitekim yapılan araştırmalar, duyguların yoğun olarak yaşandığı meslek gruplarından biri olan öğretmenlik mesleğinde tükenmişliğin gelişebileceği üzerinde yoğunlaşmaktadır (Doğan, Demir ve Türkmen, 2016; Poyraz ve Sürücüoğlu, 2015).

Tükenmişlik, işte yoğun strese tepki olarak ortaya çıan ve duygusal, tutumsal, davranışsal öğeleri barındıran, geçici bir yorgunluk ya da zorlanmadan ziyade bireyin işinden soğuması ile sonuçlanan kalıcı bir durum olarak tanımlanmaktadır (Avşaroğlu, Deniz ve Kahraman, 2005). Tükenmişliğin sonuçları göz önüne alındığında istenmeyen bir durum olduğu görülmekle birlikte, öğretmenlerin eğitim faaliyetlerinde duygusal emeği kullanmalarının tükenmişliğe yol açabileceği de düşünülmektedir (Poyraz ve Sürücüoğlu, 2015; Tokmak, 2014). Tüm bu bilgilerden hareketle, kaynaştırma uygulamasını yürüten öğretmenlerin duygusal emek ve tükenmişlik düzeylerinin bazı değişkenlere göre farklılaşıp farklılaşmadığını belirlemek ve duygusal emek ile tükenmişlik düzeyleri arasında ilişki olup olmadığını saptamak araştırmanın amacını olușturmaktadır.

\section{Yöntem}

Bu bölümde araştırmanın modeli, çalışma grubu, veri toplama araçları ve verilerin analizi üzerinde durulacaktır. 


\section{Araştırmanın Modeli}

Araştırma, Çankırı İl Milli Eğitim Müdürlügü’ne bağlı olan ve sınıfında kaynaştırma öğrencisi bulunan ilk ve ortaöğretim kurumlarındaki öğretmenlerin duygusal emek ve tükenmişlik düzeylerinin incelenmesi amacıyla yapılan tanımlayıcı bir çalışmadır. Tanımlayıcı çalışma, nicel araştırma yöntemlerinde en çok kullanılan bir teknik olup, araştırılmak istenen konu hakkında, o konuyu yaşamış bireylerden oluşan geniş bir örneklemde, geçerlik ve güvenirliği yapılan ölçeklerle bilgilerin kısa sürede toplanmasını sağlamaktadır (Büyüköztürk, Kılıç-Çakmak, Akgün, Karadeniz ve Demirel, 2016).

\section{Çalışma Grubu-Evren Örneklem}

Araştırma Çankırı İl Milli Eğitim Müdürlüğü’ne bağlı olan ve sınıfında kaynaştırma öğrencisi bulunan ilk ve ortaöğretim kurumlarındaki öğretmenlerle gerçekleştirilmiştir. Araştırmada amaçlı örnekleme yöntemi kullanılarak 70 öğretmene ulaşılmıştır. Araştırmaya dahil edilen öğretmenlerin \%50'sinin kadın ve \%50'sinin erkek öğretmen olduğu, \%42,9'unun 21-30 yaş, \%32,9’unun 37 ve üstü yaş, \%24,3’ünün 31-36 yaş grubunda olduğu, çoğunluğun $(\% 78,6)$ lisans mezunu ve evli $(\% 85,7)$ olduğu belirlenmiştir. Öğretmenlerin \%55,7'si ortaokulda görev yaparken, \%31,4'ünün 16 yll ve üstü, \%27,1'inin 6-10 y1l, \%22,9'unun 11-15 yıl, \%18,6’sının 1-5 yıllık mesleki kıdeme sahip olduğu, \%64,3'ünün sınıfında zihinsel, \%20'sinin sınıfinda öğrenme güçlügü, \%15,7’sinin sınıfinda fiziksel, konuşma ve dil, işitme ve görme yetersizliğine sahip öğrencinin bulunduğu belirlenmiştir.

\section{Veri Toplama Araçları}

Araştırmada veriler, "Genel Bilgi Formu”, "Duygusal Emek Ölçeğì" ve "Tükenmişlik Ölçeği” ile toplanmıştır.

\section{Genel Bilgi Formu}

Araştırmaya dahil edilen ve kaynaştırma uygulamasını yürüten öğretmenlerin cinsiyetlerine, yaş, mesleki kıdem, kaynaştırma öğrencisinin yetersizlik durumuna ilişkin bilgileri belirlemek amacıyla araştırmacılar tarafindan hazırlanan sorulardan oluşmaktadır.

\section{Duygusal Emek Ölçĕgi}

Diefendorff, Croyle ve Grooserand (2005) tarafindan geliştirilen ve Basım ve Begenirbaş (2012) tarafindan Türkçeye uyarlanan ölçek, üç alt boyut ve 13 maddeden oluşmaktadır. Ölçek, yüzeysel rol yapma, derinden rol yapma ve doğal duygular alt boyutlarından oluşmaktadır. Ölçekteki Cronbach Alfa katsayıları yüzeysel rol yapma alt boyutu için .92; derinden rol yapma alt boyutu için .85 ve doğal duygular alt boyutu için .83 olarak bulunmuştur (Diefendorff vd., 2005). Araştırma kapsamında ise Cronbach Alfa katsayıları, yüzeysel rol yapma alt boyutu için .85; derinden rol yapma alt boyutu için .91 ve doğal duygular alt boyutu için .81 olarak bulunmuştur. 


\section{Maslach Tükenmişlik Ölçĕgi}

Maslach ve Jackson (1981) tarafindan geliştirilen ve Ergin (1992) tarafından Türkçeye uyarlanan ölçek, duygusal tükenme, duyarsızlaşma ve kişisel başarıda azalma alt boyutlarından meydana gelmektedir. Toplamda 22 maddeden oluşan ve beşli likert tipi bir ölçektir. Ergin (1992) Türkçeye uyarlama çalışmasında, ölçeğin alt boyutlarındaki Cronbach Alfa katsayılarını duygusal tükenme alt boyutu için .83; duyarsızlaşma alt boyutu için .65 ve kişisel başarıda azalma alt boyutu için .72 olarak bulmuştur. Araştırma kapsamında Cronbach Alfa değerleri ise duygusal tükenme alt boyutu için .83; duyarsızlaşma alt boyutu için .84 ve kişisel başarıda azalma alt boyutu için .81 olarak bulunmuştur.

\section{Verilerin Analizi}

Kaynaştırma uygulamasını yürüten öğretmenlerin duygusal emek ve tükenmişlik ölçeğinden aldıkları puanların normal dağllım gösterip göstermediğini belirlemek için örneklem büyüklügü̈nün 50'den fazla olması nedeniyle Kolomogorov Smirnov test sonuçları ile Kurtosis ve Skewness değerlerine bakılmıştır. Yapılan normallik analizi sonucunda, dağılımın normal dağılım göstermediği saptanarak nonparametirk testler kullanılmıştır. Sosyodemografik değişkenlere göre duygusal emek ve tükenmişlik ölçeği alt boyutları arasında anlamlı farkllık olup olmadığı Mann Whitney U ve Kruskal Wallis testleri ile incelenmiş̧tir. Anlamlı farklılı̆̆ı olduğu durumlarda anlamlı farklılığın hangi alt gruplardan kaynaklandığını belirlemek için Mann Whitney U test sonuçlarına bakılmıştır. Duygusal emek ölçeği alt boyutları ile tükenmişlik ölçeği alt boyutları arasındaki ilişkinin belirlenmesi için nonparametrik testlerde kullanılan Spearman Korelasyon analizine bakılmışır.

\section{Bulgular ve Tartışma}

Bu bölümde elde edilen sonuçlar tablolar halinde sunulmuştur.

Tablo 1. Kaynaştırma uygulamasını yürüten öğretmenlerin cinsiyetlerine göre duygusal emek ve tükenmişlik ölçeği alt boyutlarına ilişkin ortalamalar ve Mann Whitney U testi sonuçları

\begin{tabular}{lllllll}
\hline Alt Boyutlar & Cinsiyet & $\mathbf{n}$ & $\begin{array}{l}\text { Siralar } \\
\text { ortalamas1 }\end{array}$ & $\begin{array}{l}\text { Siralar } \\
\text { toplami }\end{array}$ & $\mathbf{U}$ & $\mathbf{p}$ \\
\hline Duygusal & & & & & & \\
Emek Ölçeği & Kadın & 35 & 30,26 & 1059 & 429 & .03 \\
Yüzeysel Rol & Erkek & 35 & 40,74 & 1426 & & \\
& & & & & & \\
Derinden Rol & Kadın & 35 & 30,34 & 1062 & 432 & .03 \\
& Erkek & 35 & 40,66 & 1423 & & \\
Doğal & Kadın & 35 & 38,07 & 1332,50 & 522,50 & .28 \\
Duygular & Erkek & 35 & 32,93 & 1152,50 & & \\
Tükenmişlik & & & & & & \\
Ölçeği & & & & & & \\
Duygusal & Kadın & 35 & 37,56 & 1314,50 & 540,50 & .39 \\
Tükenme & Erkek & 35 & 33,44 & 1170,50 & & \\
Duyarsizlaşma & Kadın & 35 & 34,99 & 1224,50 & 594,50 & .83 \\
Kişisel & Erkek & 35 & 36,01 & 1260,50 & & \\
Başarlda & Kadın & 35 & 34,63 & 1212 & 582 & .72 \\
Azalma & Erkek & 35 & 36,37 & 1273 & & \\
\hline
\end{tabular}


Tablo 1'e göre, kaynaştırma uygulamasını yürüten öğretmenlerin duygusal emek ölçeği alt boyutlarından yüzeysel rol alt boyutu $(\mathrm{U}=429 ; \mathrm{p}<.05)$ ve derinden rol alt boyutu $(\mathrm{U}=432 ; \mathrm{p}<.05)$ sira ortalamalarının cinsiyete göre anlamlı düzeyde farklı olduğu belirlenmiştir. Duygusal emek ölçeğinin alt boyutlarından derinden rol yapma ve yüzeysel rol yapma al boyutlarında erkek öğretmenlerin sıra ortalamalarının, kadın öğretmenlerin sıra ortalamalarına göre daha yüksek olduğu görülmektedir. Yüzeysel rol yapma ve derinden rol yapma alt boyutlarında erkek öğretmenlerin sıra ortalamasının yüksekliğini, kadınların doğaları gereği kendilerinden beklenen başkalarının duygularını anlamak, onlarla empati yapabilmek ve sonucunda da doğal duygularla davranabilmelerine bağlamak mümkün görülmektedir (Wong ve Wang, 2009). Derinden rol yapma, kişinin kendi içindeki duygulara odaklanmasını (Brotheridge ve Grandey, 2002), yüzeysel rol ise kişinin gerçekten hissettiklerini tamamen maskeleyerek davranmasını gerektirmektedir (Grandey, 2003). Buda erkek öğretmenlerin sıra ortalamalarının yüksekliğini açıklayabilir. Genelde erkekler, olumlu duygular yerine, daha olumsuz duygularla hareket etme potansiyellerine sahip oldukları gibi, toplum tarafından kendilerinden beklenilen davranışları da bu şekilde yerine getirmektedirler (Özgen, 2010). Duygusal emek üzerinde cinsiyetin etkisini belirlemeye yönelik çalışmalarda da, erkeklerin kadınlara göre daha fazla derin davranış (Begenirbaş, 2013) ve yüzeysel davranış (Türkay, Aydın ve Taşar, 2011), kadınların ise daha fazla doğal davranış sergiledikleri bulunmuştur (Begenirbaş, 2013).

Öğretmenlerin tükenmişlik düzeyi sıra ortalamalarının cinsiyete göre anlamlı düzeyde farklı olmadığ1 belirlenmiştir ( $\mathrm{p}>$.05). Tükenmişlik ile cinsiyetin etkisini araştıran çalısmalarda da benzer şekilde anlamlı farkl11ıklar bulunamamıştır (Gündüz, 2005; Kayan- Fadlelmula, 2014; Yavuz ve Özgür, 2016). Arada anlamlı farklılık çıkmamasını, gerek erkeklerin gerekse kadınların meslek hayatında aynı şekilde yer almaları ve aynı şekilde tükenmişliğe maruz kalmalarıyla, her iki grupta da bulunan kaynaştırma öğrencisiyle açıklamak mümkün görülmektedir (Sadioğlu, Bilgin, Batu ve Okal, 2013). 
Tablo 2. Kaynaştırma uygulamasını yürüten öğretmenlerin yaşlarına göre duygusal emek ölçeği alt boyutlarına ve tükenmişlik ölçeği alt boyutlarına ilişkin ortalamalar ve Kruskal Wallis testi sonuçları

\begin{tabular}{|c|c|c|c|c|c|c|c|}
\hline Alt Boyutlar & Yaş & $\mathrm{n}$ & $\begin{array}{l}\text { Siralar } \\
\text { ortalamas1 }\end{array}$ & $\mathrm{X}^{2}$ & Sd & $\mathrm{p}$ & $\begin{array}{l}\text { Anlamli } \\
\text { farklilık }\end{array}$ \\
\hline \multicolumn{8}{|l|}{ Duygusal } \\
\hline \multicolumn{8}{|l|}{ Emek Ölçeği } \\
\hline \multirow[t]{3}{*}{ Yüzeysel Rol } & $21-30^{1}$ & 30 & 31,23 & & & & \\
\hline & $31-36^{2}$ & 17 & 36,82 & 2,66 & 2 & .26 & \\
\hline & 37 ve üstü 3 & 23 & 40,09 & & & & \\
\hline \multirow[t]{3}{*}{ Derinden Rol } & $21-30^{1}$ & 30 & 33,18 & & & & \\
\hline & $31-36^{2}$ & 17 & 29,06 & 5,64 & 2 & .06 & \\
\hline & 37 ve üstü ${ }^{3}$ & 23 & 43,28 & & & & \\
\hline Doğal & $21-30^{1}$ & 30 & 27,18 & & & & \\
\hline \multirow[t]{2}{*}{ Duygular } & $31-36^{2}$ & 17 & 39,41 & 9,49 & 2 & .01 & $2-1$ \\
\hline & 37 ve üstü 3 & 23 & 43,46 & & & & $3-1$ \\
\hline \multicolumn{8}{|l|}{ Tükenmişlik } \\
\hline Duygusal & $21-30^{1}$ & 30 & 32 & 2,41 & 2 & .3 & \\
\hline \multirow{2}{*}{ Tükenme } & $31-36^{2}$ & 17 & 41,53 & & & & \\
\hline & 37 ve üstü ${ }^{3}$ & 23 & 35,61 & & & & \\
\hline \multirow[t]{3}{*}{ Duyarsızlaşma } & $21-30^{1}$ & 30 & 38,27 & & & & \\
\hline & $31-36^{2}$ & 17 & 36,65 & 1,76 & 2 & .41 & \\
\hline & 37 ve üstü 3 & 23 & 31,04 & & & & \\
\hline Kişisel & $21-30^{1}$ & 30 & 32,83 & & & & \\
\hline Başarıda & $31-36^{2}$ & 17 & 33,06 & 2,37 & 2 & .31 & \\
\hline Azalma & 37 ve üstü ${ }^{3}$ & 23 & 40,78 & & & & \\
\hline
\end{tabular}

Tablo 2'de görüldüğü gibi kaynaştırma uygulamasını yürüten öğretmenlerin duygusal emek ölçeği alt boyutlarından doğal duygular alt boyutu $\left(\mathrm{x}^{2}=9,49 ; \mathrm{p}<.05\right)$ sıra ortalamalarının yaşa göre anlamlı farklılık gösterdiği bulunmuştur. Duygusal emek ölçeğinin alt boyutlarından doğal duygu alt boyutunda 31-36 yaş grubunda olan öğretmenlerin sıra ortalamaları ve 37 ve üstü yaş grubunda olan öğretmenlerin sıra ortalamaları 21-30 yaş grubunda olan öğretmenlerin sıra ortalamalarına göre yüksek bulunmuştur. Bu durum yaşın artmasıyla birlikte çalısanların duygularını daha rahat olarak ifade edebilme kapasiteleriyle açıklanabilir (Kruml ve Geddes, 2000). Yaşın duygusal emek üzerinde yordayıcı etkisini belirleyebilmek amacıyla yapılan çalışmalarda da, yaşın artmasına paralel olarak doğal duygularla davranma sıklığının arttığı bulunmuştur (Cheung ve Tang, 2010; Dahling ve Perez, 2010).

Öğretmenlerin tükenmişlik ölçeği alt boyutu sıra ortalamalarının yaşa göre anlamlı düzeyde farklı olmadığ belirlenmiştir ( $\mathrm{p}>$.05). Tükenmişlikle yaş arasındaki farklılığı belirlemek amacıyla yapılan çalışmalarda da, bu bulguyu destekleyen sonuçlara ulaşılmıştır (Dere- Çiftçi, 2015; Seferoğlu, Yıldız ve Avc1-Yüksel, 2014). 
Tablo 3. Kaynaştırma uygulamasını yürüten öğretmenlerin medeni durumlarına göre duygusal emek ölçeği alt boyutlarına ve tükenmişlik ölçeği alt boyutlarına ilişkin ortalamalar ve Mann Whitney U testi sonuçları

\begin{tabular}{|c|c|c|c|c|c|c|}
\hline Alt Boyutlar & $\begin{array}{l}\text { Medeni } \\
\text { Durum }\end{array}$ & $\mathrm{n}$ & $\begin{array}{l}\text { Siralar } \\
\text { ortalamas1 }\end{array}$ & $\begin{array}{l}\text { Siralar } \\
\text { toplamı }\end{array}$ & $\mathbf{U}$ & $\mathrm{p}$ \\
\hline \multicolumn{7}{|l|}{ Duygusal } \\
\hline Emek Ölçeği & Evli & 60 & 34,42 & 2065 & 235 & .3 \\
\hline Yüzeysel Rol & Bekar & 10 & 42 & 420 & & \\
\hline \multirow[t]{2}{*}{ Derinden Rol } & Evli & 60 & 35,58 & 2134,50 & 295,50 & .94 \\
\hline & Bekar & 10 & 35,05 & 350,50 & & \\
\hline Doğal & Evli & 60 & 37,24 & 2234,50 & 195,50 & .07 \\
\hline Duygular & Bekar & 10 & 25,35 & 250,50 & & \\
\hline \multicolumn{6}{|l|}{ Tükenmişlik } & \\
\hline Duygusal & Evli & 60 & 34,28 & 2056,50 & 226,50 & .21 \\
\hline Tükenme & Bekar & 10 & 42,85 & 428,50 & & \\
\hline \multirow[t]{2}{*}{ Duyarsızlaşma } & Evli & 60 & 33,58 & 2015 & 185 & .05 \\
\hline & Bekar & 10 & 47 & 430 & & \\
\hline \multicolumn{7}{|l|}{ Kişisel } \\
\hline Başarıda & Evli & 60 & 36,46 & 2187,50 & 242,50 & .33 \\
\hline Azalma & Bekar & 10 & 29,75 & 297,50 & & \\
\hline
\end{tabular}

Tablo 3'de kaynaştırma uygulamasını yürüten öğretmenlerin duygusal emek ölçeği alt boyutları sıra ortalamalarının medeni duruma göre anlamlı farklılık göstermediği bulunmuştur ( $\mathrm{p}>.05)$. Yapılan çalışmalar medeni durumun duygusal emek üzerinde anlamlı farklılığa neden olmadığı yönünde olmuştur (Kaya, 2014).

Öğretmenlerin tükenmişlik ölçeği alt boyutlarından duyarsızlaşma alt boyutu (U=185; p<.05) sıra ortalamalarının medeni duruma göre anlamlı farkll1ık gösterdiği bulunmuştur. Duyarsızlaşma alt boyutunda bekar öğretmenlerin sıra ortalamaları, evli öğretmenlerin sıra ortalamalarına göre daha yüksek bulunmuştur. Bu durumu bekar olan öğretmenlerin evli olan öğretmenler gibi gün içerisinde yaşadıkları ve sıkıntılarını paylaşabilecek bir destekten yoksun olmalarına bağlamak mümkün görülmektedir. Çünkü doyurucu ilişkilerin hüküm sürdüğü, etkili bir aile yapısına sahip olmak onlarla sorunlarını paylaşmak tükenmişliğin azalmasında etkili görülmektedir. Yapılan araştırmalar, evli olan öğretmenlerin tükenmişlik düzeylerinin bekar olan öğretmenlere göre daha düşük yönde çıktığını göstermektedir (Kalkan-Dişbudak, 2016; Kırllmaz, Çelen ve Sarp, 2003). 
Tablo 4. Kaynaştırma uygulamasını yürüten öğretmenlerin mesleki kıdem durumuna göre duygusal emek ölçeği alt boyutlarına ve tükenmişlik ölçeği alt boyutlarına ilişkin ortalamalar ve Kruskal Wallis testi sonuçları

\begin{tabular}{|c|c|c|c|c|c|c|c|}
\hline Alt Boyutlar & $\begin{array}{l}\text { Mesleki } \\
\text { Kidem }\end{array}$ & $\mathrm{n}$ & $\begin{array}{l}\text { Siralar } \\
\text { ortalamas1 }\end{array}$ & $\mathrm{X}^{2}$ & Sd & $p$ & $\begin{array}{l}\text { Anlamli } \\
\text { fark }\end{array}$ \\
\hline \multicolumn{8}{|l|}{ Duygusal } \\
\hline \multirow[t]{4}{*}{ Yüzeysel Rol } & $1-5 \mathrm{yl}^{1}$ & 13 & 26,54 & & & & \\
\hline & $6-10 \mathrm{yll}^{2}$ & 19 & 33,82 & & & & \\
\hline & $11-15 \mathrm{yl}^{3}$ & 16 & 37,28 & 4,52 & 3 & .21 & \\
\hline & $\begin{array}{l}16 \text { yll ve } \\
\text { üstü }{ }^{4}\end{array}$ & 22 & 40,95 & & & & \\
\hline \multirow{4}{*}{ Derinden Rol } & $1-5 \mathrm{yll}^{1}$ & 13 & 41,81 & & & & \\
\hline & $6-10 \mathrm{yyl}^{2}$ & 19 & 27,66 & & & & $1-2$ \\
\hline & $11-15 \mathrm{yll}^{3}$ & 16 & 29,41 & 8,75 & 3 & .03 & $4-2$ \\
\hline & $\begin{array}{l}16 \text { yll ve } \\
\ddot{u ̈ s t u ̈}^{4}\end{array}$ & 22 & 42,98 & & & & \\
\hline Doğal & $1-5 \mathrm{yl}^{1}{ }^{1}$ & 13 & 34,81 & & & & \\
\hline \multirow[t]{3}{*}{ Duygular } & $6-10 \mathrm{yll}^{2}$ & 19 & 31,11 & & & & \\
\hline & $11-15 \mathrm{yll}^{3}$ & 16 & 27,81 & 8,58 & 3 & .03 & 4-2 \\
\hline & $\begin{array}{l}16 \text { yll ve } \\
\text { üstü }{ }^{4}\end{array}$ & 22 & 45,30 & & & & 4-3 \\
\hline \multicolumn{8}{|l|}{$\begin{array}{l}\text { Tükenmişlik } \\
\text { Ölceŏgi }\end{array}$} \\
\hline Duygusal & $1-5 \mathrm{yll}^{1}$ & 13 & 25,77 & & & & \\
\hline \multirow[t]{3}{*}{ Tükenme } & $6-10 \mathrm{yyl}^{2}$ & 19 & 39,92 & 4,10 & 3 & .25 & \\
\hline & $11-15 \mathrm{yll}^{3}$ & 16 & 37,59 & & & & \\
\hline & $\begin{array}{l}16 \text { yll ve } \\
\text { üstü }^{4}\end{array}$ & 22 & 35,91 & & & & \\
\hline \multirow[t]{4}{*}{ Duyarsızlaşma } & $1-5 \mathrm{yl}^{1}$ & 13 & 32,54 & & & & \\
\hline & $6-10 \mathrm{yil}^{2}$ & 19 & 35,42 & 4,20 & 3 & .24 & \\
\hline & $11-15 \mathrm{yll}^{3}$ & 16 & & & & & \\
\hline & $\begin{array}{l}16 \text { yll ve } \\
\text { usstü }{ }^{4}\end{array}$ & 22 & 31,14 & & & & \\
\hline Kisisel & $1-5 \mathrm{yll}^{1}$ & 13 & 36,08 & & & & \\
\hline Başarıda & $6-10 \mathrm{yl}^{2}$ & 19 & 34,18 & & & & \\
\hline \multirow{2}{*}{ Azalma } & $11-15 \mathrm{yl}^{3}$ & 16 & 29,81 & 2,70 & 3 & .44 & \\
\hline & $\begin{array}{l}16 \text { yll ve } \\
\text { üstü }\end{array}$ & 22 & 40,43 & & & & \\
\hline
\end{tabular}

Tablo 4'e göre kaynaştırma uygulamasını yürüten öğretmenlerin duygusal emek ölçeği alt boyutlarından derinden rol alt boyutu $\left(\mathrm{x}^{2}=8,75 ; \mathrm{p}<.05\right)$ ve doğal duygular alt boyutu $\left(\mathrm{x}^{2}=8,58 ; \mathrm{p}<.05\right)$ sira ortalamalarının mesleki kıdeme göre anlamlı farklılık gösterdiği bulunmuştur. Derinden rol alt boyutunda 1-5 yıllık mesleki kıdeme sahip olan öğretmenlerin sıra ortalamaları, 6- 10 yıllık mesleki kıdeme sahip olan öğretmenlerin sıra ortalamalarından yüksek bulunurken, 16 yıl ve üstü mesleki kıdeme sahip olan ögretmenlerin derinden rol alt boyutu sıra ortalamaları, 6-10 yıllık mesleki kıdeme sahip olan öğretmenlerin sıra ortalamalarından ve 11-15 yllık mesleki kıdeme sahip olan öğretmenlerin sıra ortalamalarından yüksek bulunmuştur. Doğal duygular alt boyutunda ise 16 yıl ve üstü mesleki kıdeme sahip olan ögretmenlerin sıra ortalamaları 6- 10 yıl ve 11-15 ylllk mesleki kıdeme sahip olan öğretmenlerin sıra ortalamalarından yüksek bulunmuştur. Her iki alt boyutta 16 yıl ve üzeri mesleki kıdeme sahip olan öğretmenlerin sıra ortalamalarının yüksekliğini tecrübe düzeylerinin artmasına bağlamak mümkünken, 6-10 yıllık mesleki kıdeme sahip olan öğretmenlerin sıra ortalamalarının 
yüksekliğini, meslek hayatlarının başlanında olmalarından dolayı daha az deneyime sahip olmaları ve buna bağlı olarak duygularında belirsizlik yaşamaları sonucunda derinden rol davranışını kullanmaları ile sonuçlandığını düşünmek mümkündür (Kruml ve Geddes, 2000). Mesleki kıdemin duygusal emek üzerindeki etkisini belirlemek amacıyla yapılan çalışmalarda da, mesleki kıdem arttıkça, duygusal emek davranışının arttığı sonucuna ulaşılmıştır (Begenirbaş, 2013; Cheung ve Tang, 2010; Dahling ve Perez, 2010).

Tükenmişlik ölçeği alt boyutlarında öğretmenlerin sıra ortalamalarının mesleki kıdeme göre anlamlı farklılık göstermediği bulunmuştur ( $\mathrm{p}>$.05). Yapılan araştırmalarda da mesleki kıdemin tükenmişliği etkilemediği sonuçları, araştırma bulgularını desteklemektedir (Dağlı, 2006; Özgül ve Atan, 2016; Yavuz ve Özgür, 2016).

Tablo 5. Kaynaştırma uygulamasını yürüten öğretmenlerin sınıflarındaki kaynaştırma öğrencisinin yetersizlik türüne göre duygusal emek ölçeği ve tükenmişlik ölçeği alt boyutlarına ilişkin ortamalar ve Kruskal Wallis testi sonuçları

\begin{tabular}{|c|c|c|c|c|c|c|c|}
\hline Alt Boyutlar & $\begin{array}{l}\text { Yetersizlik } \\
\text { türü }\end{array}$ & $\mathrm{n}$ & $\begin{array}{l}\text { Siralar } \\
\text { ortalamas1 }\end{array}$ & $\mathbf{X}^{2}$ & Sd & $\mathrm{p}$ & $\begin{array}{l}\text { Anlamlı } \\
\text { fark }\end{array}$ \\
\hline \multicolumn{8}{|l|}{ Duygusal } \\
\hline \multicolumn{8}{|l|}{ Emek Ölçeği } \\
\hline \multicolumn{8}{|l|}{ Yüzeysel Rol } \\
\hline & Zihinsel $^{1}$ & 45 & 33,82 & & & & \\
\hline & Fiziksel & 11 & 34,14 & 1,84 & 2 & .4 & \\
\hline & & 14 & 41,96 & & & & \\
\hline & $\begin{array}{l}\text { Öğrenme } \\
\text { güclüğğ }{ }^{3}\end{array}$ & & & & & & \\
\hline \multirow[t]{4}{*}{ Derinden Rol } & Zihinsel ${ }^{1}$ & 45 & 33,38 & & & & \\
\hline & Fiziksel & 11 & 36,55 & 1,79 & 2 & .41 & \\
\hline & vd. ${ }^{2}$ & 14 & 41,50 & & & & \\
\hline & $\begin{array}{l}\text { Öğrenme } \\
\text { güçlüğ̈̈ }\end{array}$ & & & & & & \\
\hline Doğal & Zihinsel $^{1}$ & 45 & 36,04 & & & & \\
\hline \multirow[t]{4}{*}{ Duygular } & Fiziksel & 11 & 35,68 & 0,16 & 2 & .92 & \\
\hline & $\mathrm{vd}^{2}{ }^{2}$ & 14 & 33,61 & & & & \\
\hline & Öğrenme & & & & & & \\
\hline & güçlüğ̈̈ ${ }^{3}$ & & & & & & \\
\hline \multirow[t]{4}{*}{ Duyarsızlaşma } & Zihinsel $^{1}$ & 45 & 31,11 & & & & \\
\hline & Fiziksel & 11 & 42,82 & 6,05 & 2 & .05 & $3-1$ \\
\hline & $\mathrm{vd} .^{2}$ & 14 & 28,82 & & & & \\
\hline & $\begin{array}{l}\text { Öğrenme } \\
\text { güclüğğ }{ }^{3}\end{array}$ & & & & & & \\
\hline Kişisel & Zihinsel $^{1}$ & 45 & 37,61 & & & & \\
\hline Başarida & Fiziksel vd ${ }^{2}$ & 11 & 35,36 & 2,05 & 2 & .36 & \\
\hline Azalma & $\begin{array}{l}\text { Öğrenme } \\
\text { güclüğ̈̆33 }\end{array}$ & 14 & 28,82 & & & & \\
\hline
\end{tabular}

Tablo 5'e göre kaynaştırma uygulamasını yürüten öğretmenlerin duygusal emek ölçeğinin alt boyutlarından doğal duygu alt boyutu $\left(\mathrm{x}^{2}=10,81 ; \mathrm{p}<.05\right)$ sıra ortalamalarının sınıftaki kaynaştırma öğrencisinin yetersizlik türüne göre anlamlı farklllık gösterdiği bulunmuştur. Buna göre duygusal emek ölçeği alt boyutlarından doğal duygular alt boyutunda sınıfında zihinsel yetersizliğe sahip öğrenci bulunan öğretmenlerin sıra ortalamalarının diğer gruplara göre daha yüksek olduğu görülmektedir. Kaynaştırma 
uygulamasının başarıya ulaşmasında en önemli etkenlerden birinin öğretmen olduğu vurgulanmaktadır (Aral ve Gürsoy, 2011). Bu durumda öğretmenlerin doğal duygularla öğrencilerine davranabilmelerini gerektirmektedir.

Tükenmişlik düzeyi alt boyutlarından duyarsızlaşma alt boyutu $\left(\mathrm{x}^{2}=6,05 ; \mathrm{p}<.05\right)$ sıra ortalamalarının sınıftaki kaynaştırma öğrencisinin yetersizlik türüne göre anlamlı farkll1ık gösterdiği görülmektedir. Duyarsızlaşma alt boyutunda sınıfinda öğrenme güçlüğü öğrencisi bulunan öğretmenlerin sıra ortalamalarının diğer gruplara göre daha yüksek olduğu görülmektedir. Öğrenme güçlügü olan çocuklar saldırganlıktan çekingenliğe değişen geniş bir davranış yelpazesine sahip olduklarından dolayı (Aral ve Gürsoy, 2011) öğretmenler bu çocuklara gerek davranış kontrolü kazandırabilmek ve gerekse akademik yeterlilik kazandırabilmek amacıyla birebir çalışmak zorundadır (Arslan ve Arslan, 2014). Birebir çalışmak durumunda olmanın da, öğretmenlerdeki duyarsızlaşmayı arttırdığı düşünülmektedir.

Tablo 6. Kaynaştırma uygulamasının yürüten öğretmenlerin duygusal emek ölçeği ve tükenmişlik ölçeğine ait korelasyon analizi sonuçları

\begin{tabular}{lllll}
\hline & Duygusal Tükenme & Duyarsızlaşma & $\begin{array}{l}\text { Kişisel } \\
\text { Azalma }\end{array}$ & Başarıda \\
\hline Yüzeysel Rol & $\mathrm{r}=.26$ & $\mathrm{r}=.36$ & $\mathrm{r}=.11$ \\
& $\mathrm{p}<.05$ & $\mathrm{p}<.05$ & $\mathrm{p}>.05$ \\
Derinden Rol & $\mathrm{r}=.25$ & $\mathrm{r}=-.12$ & $\mathrm{r}=.27$ \\
& $\mathrm{p}<.05$ & $\mathrm{p}>.05$ & $\mathrm{p}<.05$ \\
Doğal Duygular & $\mathrm{r}=.09$ & $\mathrm{r}=-.57$ & $\mathrm{r}=.37$ \\
& $\mathrm{p}>.05$ & $\mathrm{p}<.05$ & $\mathrm{P}<.05$ & \\
\hline
\end{tabular}

Tablo 6'ya göre kaynaştırma uygulamasını yürüten öğretmenlerin duygusal emek ölçeğinin yüzeysel rol yapma alt boyutu ile tükenmişlik ölçeğinin duygusal tükenme alt boyutu $(r=.26 ; p<.05)$ ve duyarsılaşma $(\mathrm{r}=.36 ; \mathrm{p}<.05)$ arasında pozitif yönde, duygusal emek ölçeğinin derinden rol alt boyutu ile tükenmişlik ölçeğinin duygusal tükenme $(\mathrm{r}=-.25 ; \mathrm{p}<.05)$ alt boyutu arasında negatif ve kişisel başarı duygusunda azalma alt boyutu $(\mathrm{r}=.27 ; \mathrm{p}<.05)$ arasında pozitif yönde, duygusal emek ölçeğinin doğal duygular alt boyutu ile tükenmişlik ölçeğinin duyarsızlaşma alt boyutu $(\mathrm{r}=-.57 ; \mathrm{p}<.05)$ arasında negatif ve kişisel başarı duygusunda azalma alt boyutu $(\mathrm{r}=.37 ; \mathrm{p}<.05)$ arasında pozitif yönde anlamlı ilişki bulunmuştur. Kişilerin gerçekte hissettiklerini maskeleyerek farklı davranmalarını gerektiren yüzeysel rol yapma sonucunda (Grandey, 2003) kişiler gerçek duygularını ifade edemediklerinden etraflarındaki insanlara karşı yabancılaşarak duyarsızlaşma yaşayabilirler. Duyarsızlaşmanın sıklıkla yaşanması, kişilerin duygularını saklamalarıyla duygusal tükenmelerini arttırabilir (Taycan, Kutlu, Çimen ve Aydın, 2006). Kişilerin mesleklerini yerine getirirken ortama göre sergilemesi gereken duyguları gerçekten hissetmeleri sonucunda (Brotheridge ve Lee, 2003) duygusal tükenmeleri azalabilecek, buna karşllık kişisel başarı duygusunda azalma artabilecektir, öğrencilerine doğal duygularla samimi olarak yaklaşmaları ise onların etraflarına yabancılaşmalarını ve duyarsızlaşmalarını azaltabilecektir (Asforth ve Humprey, 1993). Kişilerin doğal olarak davranması ise, sorunların üstesinden gelemediği anlarda, onların kişisel başarı duygusunda azalma duygularını arttırabilir (Taycan vd., 2006). Nitekim yapılmış olan araştırmalarda da yüzeysel rol yapma ile davranan kişilerde duyarsızlaşmanın fazla olduğu (Naktiyak ve Ağırman, 2016), 
derinlemesine davranış gösteren kişilerde kişisel başarı duygusunda azalmanın fazla olduğu ve doğal duygular ile tükenmişlik arasında negatif yönde ilişkinin olduğu belirlenmiştir (Begenirbaş, 2013).

\section{Sonuç ve Öneriler}

Kaynaştırma uygulamasını yürüten öğretmenlerin duygusal emek ve tükenmişlik düzeylerinin bazı değişkenlere göre farklılaşıp farklılaşmadığını belirlemek ve duygusal emek ile tükenmişlik düzeyleri arasında ilişki olup olmadığını saptamak amacıyla yapılan araştırma sonucunda, cinsiyetin, yaşın, mesleki kıdemin, kaynaştırma öğrencisinin yetersizlik türünün duygusal emek ölçeğinin bazı alt boyutlarında, medeni durumun, kaynaştırma öğrencisinin yetersizlik türünün ise tükenmişlik ölçeğinin duyarsızlaşma alt boyutunda anlamlı farklıllğa neden olduğu görülürken, duygusal emek ile tükenmişlik ölçeğinin alt boyutları arasında anlamlı bir ilişki bulunmuştur. Araştırmadan elde edilen sonuçlar doğrultusunda;

1. Kaynaştırma uygulamasını yürüten öğretmenlere yönelik rehberlik hizmetlerinin daha etkin ve etkili şekilde sunulması,

2. Kaynaştırma öğrencisi olan öğretmenlerin aile-okul etkileşiminin daha etkili olmasının sağlanması, okul yöneticilerinin devreye girerek öğretmenlere daha fazla yardımcı olmalarının sağlanmas1,

3. Öğretmenlere özel eğitim ile ilgili bilgi ve becerilerin daha etkin ve etkili hizmet içi eğitimlerle verilmesi,

4. Öğretmen adaylarının tümüne halen uygulanmakta olan özel eğitim derslerinin etkililiğinin arttırılması ve stajlarla desteklenmesi önerilebilir.

\section{Kaynakça}

Aral, N., Gürsoy, F. (2011). Özel eğitim gerektiren çocuklar ve özel eğitime giriş. İstanbul: Morpa.

Arslan, G., Arslan, G. (2014). Zihin engelli bireylere eğitim veren öğretmenlerin tükenmişlik düzeylerinin incelenmesi (Tokat ili örneği). Eğitim Bilimleri Arasttrmalar Dergisi, 4(2), 49-66.

Asforth, B.E., Humprey, R.H. (193). Emotional labor in service roles: The influence of identity. Academic of Management, 18(1), 88-115.

Avşaroğlu, S., Deniz, E.M., Kahraman, A. (2005). Teknik öğretmenlerde yaşam doyumu, iş doyumu ve mesleki tükenmişlik düzeylerinin incelenmesi. Selçuk Üniversitesi Sosyal Bilimler Enstitïiü Dergisi, 14, 115-129.

Basım, N.H., Begenirbaş, M. (2012). Çalışma yaşamında duygusal emek: Bir ölçek uyarlama çalışması. Yönetim ve Ekonomi, 19(1), 77-90.

Begenirbaş, M. (2013). Kişiliğ̈n öğrenme stillerine etkisinde duygusal emek ve tükenmişlï̆gin aracıllk rolü: Öğretmenler üzerinde bir arasttrma Doktora Tezi, Kara Harp Okulu, Ankara.

Brotheridge, C., Grandey, A. (2002). Emotional labor and burnout: Comparing two perspectives of people work. Journal of Vocational Behavior, 60, 17-29.

Brotheridge, C. M., Lee, R.T. (2003). Development and validation of the emotional labor scale Journal of Occupational and Organizational Psychology, 76(3), 365-379. 
Brookfield, S.D. (2017). Becoming a critically reflective teacher Sanfrancisco: Jossey-Bass.

Büyüköztürk, Ş., Kllıç-Çakmak, E., Akgün, Ö.E., Karadeniz, Ş., Demirel, F. (2016). Bilimsel Araşttrma Yöntemleri Ankara: Pegem.

Cheung, F.Y., Tang, C.S. (2010). Effects of age and emotional labor strategies on job outcomes: Moderated mediation analyses. Applied Psychology Health and Well-Being, 2(3), 323-329.

Coe, R., Alaisi, C., Higgins, S., Major, L.E. (2014). What makes great teaching? http://universityofhullscitts.org.uk/scittssisite/downloads/core2.coepdf. 08.06.2017.

Coşkun, İ., Gür, T., Aykutlu, H. (2014). Hafif düzey zihin engelli bireylerin okuduğunu anlama düzeyinin belirlenmesi. Uluslararası Avrupa Sosyal Bilimler Dergisi, 5(14), 17-42.

Dağlı, A. (2006). Okul yöneticilerinin tükenmişlik düzeyleri Eurasian Journal of Educational Research, 25, 8595.

Dahling, J.J., Perez, I.A. (2010). Older worker, different actor? Linking age and emotional labor strategies Personality and Individual Differences, 48(5), 574-578.

Dere-Çiftçi, H., (2015). Özel eğitim merkezlerinde çalışan öğretmenlerin mesleki yetkinlik ve tükenmişlik düzeyleri arasındaki ilişkinin belirlenmesi Mediterranean Journal of Humanities, 1, 221-241.

Diefendorff, J.M., Croyle, M.H., Grosserand, R.H. (2005). The dimensionality and antecedents of emotional labor strategies Journal of Vocational Behavior, 66, 339-357.

Diken, İ.H. (2015). Illköğretimde kaynastrma Ankara: Pegem.

Doğan, A., Demir, R., Türkmen, E. (2016). Rol belirsizliğinin, rol çatışmasının sosyal desteğin tükenmişliğe etkisi: Devlet ve Vakıf üniversitelerinde çalışan akademik personelin tükenmişlik düzeylerinin karşılaştırılması Atatürk Üniversitesi İktisadi ve İdari Bilimler Dergisi, 30(1), 37-67.

Ergin, C. (1992). Doktor ve hemşirelerde tükenmişlik ve Maslach tükenmişlik ölçeğinin uyarlanması VII. Ulusal Psikoloji Kongresi, , 22-25 Eylül 1992, Ankara.

Fullan, M., Hargreaves, A. (2014). Teacher development and educational change. London and New York: Routledge Taylor\& Francis Group.

Grandey, A. A. (2003). When the show must go on surface acting and deep acting as determinants of emotional exhaustion and peer-rated service delivery Academy of Management Journal, 46, 86-96.

Guy, M.E., Newman, M.A., Mastracci, S.H. (2015). Emotional labor. Putting the service in public service London and New York: Routledge Taylar\& Francis Group.

Gün-Eroğlu, Ş. (2014). Örgütlerde duygusal emek ve tükenmişlik ilişkisi üzerine bir araştırma Pamukkaale Üniversitesi Sosyal Bilimler Dergisi, 19, 147-160.

Gündüz, B. (2005). İlköğretim öğrencilerinde tükenmişlik. Mersin Üniversitesi Eğitim Fakültesi Dergisi, 1(1), 152-166.

Kalkan-Dişbudak, Ş. (2016). Öğretim elemanlarmm mükemmeliyetçilik ile tükenmişlik düzeyleri arasındaki ilişkinin farklı değis̆kenler açısmdan incelenmesi Yüksek Lisans Tezi, Gaziantep Üniversitesi, Gaziantep.

Karasu, H.P., Girgin, Ü., Gürgür, H. (2015). İşitme engelli bir çocuğun okuma-yazma becerilerinin dil deneyim yaklaşımı ile desteklenmesi Turkish Online Journal of Qualitative Inquiry, 6(1), 111-144. 
Karataş, A. (2013). Öğretmen adaylar1 için meslek etiğinin önemi Marmara Coğrafya Dergisi, 25, 304-318.

Kaya, F. (2014). Duygusal emek ile tükenmişlik ve is doyumu arasindaki iliskinin incelenmesi: Aile ve Sosyal Politikalar Bakanliğg’na bağgl buzurevlerinde çalışan yaşl bakım personeline yönelik bir arasțtrma Yüksek Lisans Tezi, Celal Bayar Üniversitesi, Manisa.

Kayan- Fadlelmula, F. (2014). Akademisyenlerin tükenmişlik düzeyleri. Ondokuz Mayıs Üniversitesi Eğitim Fakeültesi Dergisi, 33(2), 424-438.

Kırllmaz, A.Y., Çelen, Ü., Sarp, N. (2003). İlköğretimde çalışan bir öğretmen grubunda "tükenmişlik durumu" araştırması. İlköğretim Online, 2(1), 2-19.

Kruml, M.S., Geddes, D. (2009). Exploring the dimensions of emotional labor: The heart of Hoeschild's work. Management Communication Quarterly, 14(8), 8-49.

Maslach, C., Jackson, S.E. (1981). The measurement of experienced burnout Journal of Organizational Behavior, 2(2), 99-113.

Naktiyak, A., Ağırman, Ü.H. (2016). İş odaklı duygusal emek ve duygusal tükenme arasındaki ilisskide çalısan odaklı duygusal emek ve mesleki bağlllığın aracı etkisi. Atatürk Üniversitesi İktisadi ve İdari Bilimler Dergisi, 30(4), 789-809.

Özgen, I. (2010). Turizm işletmelerinde duygusal emek. Ankara: Detay.

Özgül, F., Atan, T. (2016). Öğretmenlerin tükenmişlik düzeylerinin demografik özelliklerine göre incelenmesi. Errzincan Üniversitesi Ë̆itim Fakültesi Dergisi, 18(2), 1002-1016.

Poyraz, K., Sürücüoğlu, H. (2015). İlk ve ortaöğretim okul yöneticilerinde tükenmişlik (Kütahya il merkezi örneği). Dumlupinar Üniversitesi Sosyal Bilimler Dergisi, 44, 9-23.

Sadioğlu, Ö., Bilgin, A., Batu, S., Okal, A. (2013). Sınıf öğretmenlerinin kaynaştırmaya ilişkin . sorunları, beklentileri ve önerileri. Kuram ve Uygulamada Eğitim Bilimleri, 13(3), 1743-1765.

Seferoğlu, S.S., Yıldız, H., Avc1-Yüksel, Ü. (2014). Öğretmenlerdeki tükenmişlik: Tükenmişliğin göstergeleri ve bu göstergelerin çeşitli değişkenler açısından incelenmesi. Eğitim ve Bilim, 39(174), 348-364.

Seyhan, B., Gültekin-Akduman, G. (2015). Ulusal yasalar ve yönetmelikler ile uluslararası sözleşmeler açısından engelli çocukların eğitim hakkı. Uluslararası Katılıml III. Çocuk Gelişimi ve Eğitimi Kongresi "Erken Müdahale” 11-13 May1s 2015, Hacettepe Üniversitesi, Ankara.

Şat, A., Amil, O., Özdevecioğlu, M. (2016). Duygusal zeka ve duygusal emek davranışlarının bazı demografik değişkenler açısından incelenmesi: Özel okul öğretmenleri üzerinde bir araştırma. Sosyal Bilimler Enstitïï̈ Dergisi, 39(2), 1-20.

Taycan, O., Kutlu, I., Çimen, S., Aydın, N. (2006). Bir üniversite hastanesinde çalışan hemşirelerde depresyon ve tükenmişlik düzeyinin sosyodemografik özelliklerle olan ilişkisi Anadolu Psikiyatri Dergisi, 7, 100-108.

Tokmak, İ. (2014). Duygusal emek ile işe yabancılaşma ilişkilerinde psikolojik sermayenin düzenleyici etkisi İAD İsletme Arasttrmalar Dergisi, 6(3), 134-156. 
Türkay, G., Aydın, Ü., Taşar, O. (2011). Motivasyonel ve yapısal etkenler altında duygusal emeğin işe bağlllı̆̆a etkisi. ZKÜ Sosyal Bilimler Dergisi, 7(14), 201-222.

Wong, J.Y., Wang, C.H. (2009). Emotional labor of the tour leader: An explotary study. Tourism Management, 30, 249-259.

Yavuz, M., Özgür, H. (2016). Otizm spektrum bozukluğu olan öğrencilerle çalışan öğretmenlerin mesleki tükenmişlik düzeylerinin incelenmesi. Trakya Üniversitesi Sosyal Bilimler Dergisi, 18(2), 47-67. 